\title{
KAJIAN YURIDIS SOSIOLOGIS TERHADAP TINDAK PIDANA DI BIDANG PERBANKAN
}

Oleh :

M. Zen Abdullah*

Abadi B. Darmo *

\begin{abstract}
ABSTRAK
Bank merupakan lembaga intermediasi keuangan, karena fungsiya menerima simpanan masyarakat dan menyalurkannya dalam bentuk pinjaman (kredit). Dalam melaksanakan tugas dan fungsinya tersebut, ada beberapa prinsip yang harus diperhatikan dan diterapkan dalam manajemen perbankan agar tercipta system perbankan yang tangguh, sehat, dinamis professional dan dapat dipertanggung jawabkan. Akan tetapi seringkali dalam prakteknya, tugas dan fungsi yang sedemikian bagus dan mulia seringkali dikotori oleh oknum-oknum yang memanfaatkan system yang diterapkan tersebut hanya demi keuntungan dirinya pribadi ataupun kelompoknya saja, dengan memanfaatkan kondisi keuangan dunia yang sedang goncang banyak muncul kasus-kasus pidana perbankan yang menyebabkan goncangnya perekonomian.
\end{abstract}

Kata Kunci: Tindak Pidana Perbankan, Yuridis Sosiologis

\section{A. Pendahuluan}

Lembaga Perbankan dewasa ini sudah merupakan suatu lembaga yang dibutuhkan masyarakat dalam kehidupan sehari-harinya dengan berbagai produk yang telah menyentuh hampir setiap sisi kehidupan masyarakat menyangkut transaksi keuangannya. Dan sebagai suatu lembaga yang cukup dipercaya oleh masyarakat, sudah barang tentu perbankan memegang peranan yang cukup penting dalam system perekonomian, sehingga perbankan seringkali disebut sebagai jantung dari system keuangan, karena perbankan menerima simpanan dana masyarakat dalam berbagai produk seperti tabungan, deposito, rekening giro dan sebagainya baik milik perorangan maupun perusahaan bahkan badan usaha yang dimiliki pemerintah maupun pihak swasta.

Selain berfungsi menerima dana masyarakat, perbankan juga berfungsi sebagai penyedia dana melalui kebijakan pemberian kredit juga kepada individu ataupun badan usaha yang memerlukan bantuan dana dalam kegiatan usahanya. Fungsi lain dari perbankan yang juga memegang peranan penting dalam dunia perekonomian adalah

\footnotetext{
* Pengajar Program Magister Ilmu Hukum Unbari.

* Pengajar Program Magister Ilmu Hukum Unbari.
} 
Mengedarkan uang sebagai alat pembayaran, menerapkan kebijakan uang ketat (Right money policy) maupun meningkatkan penyaluran kredit kepada masyarakat luas.

Dalam melaksanakan tugas dan fungsinya tersebut, ada beberapa prinsip yang harus diperhatikan dan diterapkan dalam manajemen perbankan agar tercipta system perbankan yang tangguh, sehat, dinamis professional dan dapat dipertanggung jawabkan. Akan tetapi seringkali dalam prakteknya, tugas dan fungsi yang sedemikian bagus dan mulia seringkali dikotori oleh oknum-oknum yang memanfaatkan system yang diterapkan tersebut hanya demi keuntungan dirinya pribadi ataupun kelompoknya saja, dengan memanfaatkan kondisi keuangan dunia yang sedang goncang (dimulai tahun 1998 saat terjadi krisis moneter yang melanda dunia) banyak muncul kasus-kasus pidana perbankan yang menyebabkan goncangnya perekonomian. Walaupun tentunya kita tidak dapat mempersalahkan hanya pada sector perbankan saja.

Untuk mempermudah urusan, transaksi yang terkait tindak pidana korupsi masih banyak dilakukan melalui sistem perbankan. Modus operandi tindak pidana korupsi semakin canggih dengan memasuki sistem keuangan, salah satunya adalah perbankan. Adanya kasus-kasus yang berada di wilayah abu-abu, dimana di satu sisi merupakan tindak kejahatan perbankan namun di sisi yang lain merupakan tindak pidana korupsi.

\section{B. Fungsi Perbankan}

Bank merupakan lembaga intermediasi keuangan, karena fungsiya menerima simpanan masyarakat dan menyalurkannya dalam bentuk pinjaman (kredit). Menurut Undang-Undang Nomor 10 tahun 1998, yang dimaksud dengan bank adalah badan usaha yang menghimpun dana dari masyarakat dalam bentuk simpanan dan menyalurkannya ke masyarakat dalam bentuk kredit dan atau bentuk-bentuk lainnya dalam rangka meningkatkan taraf hidup masyarakat banyak. Dari kedua definisi di atas dapat disimpulkan bahwa bank merupakan lembaga keuangan yang kegiatannya adalah:

1. Menghimpun dana (uang) dari masyarakat dalam bentuk simpanan. Dalam hal ini bank bertindak sebagai tempat menyimpan uang atau berinvestasi bagi masyarakat. Tujuan utama masyarakat menyimpan uang biasanya adalah untuk keamanan uangnya. Sedangkan tujuan kedua adalah untuk melakukan investasi dengan harapan memperoleh bunga dari hasil investasinya. 
2. Menyalurkan dana ke masyarakat, maksudnya bank memberikan pinjaman (kredit) kepada masyarakat yang mengajukan permohonan. Dengan kata lain, bank menyediakan dana bagi masyarakat yang membutuhakan.

3. Memberikan jasa-jasa bank lainnya, seperti pengiriman uang (transfer), penagihan surat-surat berharga yang berasal dari dalam kota (clearing), penagihan surat-surat berharga yang berasal dari luar kota dan luar negeri (inkaso), letter of credit (L/C), safe deposit box, bank garansi, bank notes, travellers cheque, dan jasa lainnya.

Sesuai peraturan perundang-undangan, kegiatan usaha bank meliputiproduk-produk yang berbasis pendanaan (funding based), pembiayaan/pinjaman(financing/lending based) dan yang berbasis jasa-layanan (fee based). Secara ringkas, kegiatan usaha bank (khususnya bank umum konvensional)yang tergolong sebagai aktivitas pendanaan adalah menghimpun dana masyarakatdalam bentuk simpanan berupa: giro, tabungan, deposito berjangka dan sertifikatdeposito. Untuk memelihara likuiditas dan meningkatkan sumber pendanaan,bank dapat menerbitkan surat pengakuan utang dan surat berharga komersial,baik di pasar uang (seperti surat berharga pasar uang/SBPU) maupun di pasarmodal (seperti surat utang jagka pendek dan obligasi).

Aktivitas pendanaan menjadi penting manakala bank mengalami kelebihan likuiditas, sementara pengguliran kredit dihadapkan pada kondisi sektor riil yangdinilai belum siap menyerapnya.Keadaan ini juga berkait dengan kebijakanmoneter oleh Bank Indonesia untuk mengendalikan tingkat inflasi, overheatingekonomi, atau nilai tukar rupiah.Fungsi treasury atau dealer bank menjadibagian penting dalam kegiatan yang tergolong investment banking ini.

Kegiatan usaha yang berkait dengan pengelolaan dana tersebut di atas dapat dilakukan dalam beberapa bentuk sebagai berikut:

a. Membeli, menjual, atau menjamin atas risiko sendiri maupun untuk kepentingan dan atas perintah nasabahnya:

b. Surat-surat wesel termasuk wesel yang diakseptasi oleh bank yangmasa berlakunya tidak lebih lama daripada kebiasaan dalam perdagangan surat-surat dimaksud;

c. Surat pengakuan utang dan kertas dagang lainnya yang masa berlakunya tidak lebih lama daripada kebiasaan dalam perdagangan surat-surat dimaksud;

d. Kertas perbendaharaan negara dan surat jaminan pemerintah (seperti obligasi pemerintah dan surat utang negara);

e. Sertifikat Bank Indonesia (SBI); 
f. Surat dagang berjangka waktu sampai dengan satu tahun (seperticommercial paper, promissory notes);

g. Obligasi;

h. Instrumen surat berharga lain yang yang berjangka waktu sampaidengan satu tahun.

i. Menempatkan dana pada, meminjam dana dari, atau meminjamkandana kepada bank lain, baik dengan menggunakan surat, saranatelekomunikasi maupun dengan wesel unjuk, cek atau saranalainnya.

j. Menerbitkan surat pengakuan utang.

k. Melakukan kegiatan dalam valuta asing (bagi bank umum devisa).

Tindak pidana perbankan diartikan sebagai istilah yang menampung segala jenis perbuatan melanggar hukum yang berhubungan dengan kegiatan-kegiatan dalam menjalankan usaha bank, jadi disini bank dalam arti luas sebagai "korban" (biasanya pelaku didakwa berdasarkan KUHPidana) biasanya dalam bidang lalu lintas pembayaran giral dan peredaran uang, maupun bank sebagai "pelaku" (biasanya bank didakwa berdasarkan UU tentang Pokok-Pokok perbankan, UU No. 14/1967 sebagai peraturan administratif yang memuat sanksi-sanksi pidana) yaitu pemberitahuan keterangan keuangan nasabah dan larangan-larangan bidang usaha (Pasal 38 UU Perbankan). ${ }^{1}$

Tindak kejahatan yang berkait dengan aktivitas pendanaan terutama dipicuoleh keadaan tidak memadainya sistem, infrastratruktur dan sumberdaya manusiabank.Dalam konteks manajemen risiko, hal ini tergolong sebagai risiko operasional.Oleh karena itu, pencegahan dan atau mitigasi risiko kejahatan jenisini lebih banyak difokuskan pada peningkatan kapasitas lembaga bank itu sendiri.Salah satu strategi yang kini telah menjadi kebijakan otoritas adalah kewajibanmenerapkan prinsip-prinsip mengenal nasabah (know your custumers/ KYC) bagibank dan lembaga-lembaga keuangan lain.

Di antara perhatian pokok yang ditujukan bagi upaya menghindari risikokejahatan dimaksud adalah:

- Jenjang otorisasi dan pemisahan fungsi pegawai bank dalammembuat/mengajukan, memeriksa, dan menyetujui aplikasi pembukaandan pengelolaan/transaksi rekening nasabah.

\footnotetext{
${ }^{1}$ Mardjono Reksodiputro, 2007. Kemajuan Pembangunan Ekonomi dan Kejahatan; Buku Ke Satu, Pusat Pelayanan Keadilan Dan Pengabdian Hukum, Jakarta.
} 
- Mekanisme builtin control, seperti kewajiban adanya dual signature dandual custodianship terhadap seluruh dokumen intern bank, sepertidalam proses pembukuan dan pengelolaan uang tunai di brankas (vault).

- Kehati-hatian dalam melakukan verifikasi identitas nasabah, termasukverifikasi dokumen-dokumen yang disyaratkan dalam pembukaanrekening.

- Kehati-hatian dalam melakukan verifikasi instruksi nasabah dalambertransaksi tunai maupun non tunai, baik langsung maupun melaluielectronic atau phone banking.

- Penggunaan kertas/formulir yang free number form dalam seluruhdokumen intern maupun dokumen yang berkait atau ditandatanganinasabah.

- Dalam hal kegiatan penempatan dana antar bank, pasar uang dan pasarmodal, hal-hal tersebut di atas harus ditempuh lebih seksama karenamenyangkut verifikasi transaksi dan dokumen antarlembaga sertaberkait dengan kondisi pasar yang kompleks dan cenderung terusberubah.

- Kegiatan pengawasan yang konsisten oleh satuan pengawas intern bankuntuk menegakkan aspek kepatuhan (compliance) terhadap seluruhsistem dan prosedur dalam pembukaan-pengelolaan rekening nasabah.

Dalam kegiatan penyaluran kredit (lending), beberapa jenis kredit menurutpeggunaannya adalah: kredit modal kerja, kredit investasi dan kredit konsumsi.Potensi kejahatan dari sisi penyaluran kredit memiliki rentang kendali yang lebihluas dibanding dalam aktivitas pendanaan, karena berhadapan dengan pihakketiga (debitur) yang sejak awal memiliki motiv untuk memperoleh (mengeruk)dana bank. Kecakapan seorang account officer dalam melakukan analisiskeuangan dan analisis kredit dituntut tidak saja dalam tataran praktik, melainkanketajaman intuisinya dalam mengantisipasi kemungkinan adanya rekayasaproposal kredit beserta dokumen yang menyertainya, utamanya rekayasa laporankeuangan dan proyeksi bisnis yang akan dibiayai. Di samping itu, dalammengatasi kredit bermasalah, restrukturisasi kredit seringkali harus berhadapandengan rekayasa keuangan dan bisnis yang lebih menguntungkan debitur danmelahirkan potensi risiko baru bagi bank.

Sebagaimana dalam pendanaan, potensi risiko kejahatan dalam penyalurankredit dapat bersumber dari dalam bank sendiri, berkait dengan sistem,infrastruktur dan sumberdaya manusia.Praktik kolusi antara pejabat bank dancalon debitur seringkali menjadi penyebab utama timbulnya kredit bermasalah;lebih-lebih bila para pihak memiliki hubungan afiliasi kelompok bisnis ataukeluarga.Untuk itu, uji kepatuhan dan pengawasan 
melekat dipandang tidaklahcukup bila tidak dibarengi dengan itikad baik (moralitas) seluruh pemangkukepentingan untuk memelihara kinerja dan kesehatan bank.

Lebih khusus terdapat beberapa pokok perhatian untuk mengantisipasikredit salah sasaran, di antaranya sebagai berikut:

- $\quad$ Kepastian bahwa plafon kredit yang diajukan tidak melanggar ketentuantentang batas maksimum pemberian kredit (BMPK).

- Kepastian bahwa usaha atau proyek yang akan dibiayai tidak melanggarrambu-rambu kebijakan intern bank atau berisiko tinggi untuk dibiayaitanpa mengindahkan covenan yang disyaratkan.

- Kepastian seluruh dokumen persyaratan kredit telah dibuktikankeabsahan dan kelengkapannya, utamanya menyangkut dokumen legalseperti Akta Pendirian dan Perubahannya yang terakhir, persetujuanpengurus dan pemegang saham tentang pengajuan kredit, perijinanperusahaan, kartu identitas dan contoh tanda tangan pengurus, danlaporan keuangan audited.

- $\quad$ Kepastian telah dilakukan tinjauan lapang (call visit) secara obyektifterhadap kondisi dan sarana usaha yang dimiliki calon debitur, sertapenilaian (taksasi) barang jaminan.

- Kepastian bahwa analisis laporan keuangan dan analisis kredit telahdilakukan menurut tata cara yang benar dan lengkap sesuai system prosedur yang ada dengan didasarkan pada data dan dokumen yanglengkap dan sahih.

- Kepastian bahwa asumsi-asumsi yang dikenakan dalam menyusunproyeksi usaha dan arus kas calon debitur telah teruji secara meyakinkandengan tingkat sensitifitas yang dapat diterima sesuai ketentuan bank.

- Kepastian bahwa seluruh aspek perikatan kredit dan perikatan barangjaminan telah dilakukan sesuai hukum yang berlaku sebelum kreditdicairkan.

Kepatuhan terhadap prinsip kehati-hatian dalam menyalurkan kreditmenjadi jiwa profesi bankir, karena aspek ini yang secara langsung dapatmenurunkan kinerja usaha, tingkat kesehatan, permodalan, dan ekspektasikeuntungan yang dapat dinikmati pemilik bank.

Sesuai dengan namanya, potensi risiko kejahatan yang terkandung di dalamkegiatan layanan-jasa (fee based) sangat bergantung pada intensitas pegawaibank dalam memahami latar belakang, karakteristik dan kapasitas nasabah dalammelakukan transaksi. Konsep KYC sesungguhnya lahir atas pertimbangan bahwamotif dan modus transaksi keuangan semakin kompleks yang di dalamnyaterkandung potensi kejahatan, tindakan pencucian uang hasil kejahatan ataupraktik ilegal. 
1. Dalam prosedur yang berlaku umum, antisipasi tindak kejahatan iniutamanya terletak pada sejauh mana pegawai bank melakukan verifikasi atasinstruksi nasabah dalam melakukan transaksi, dan sejauh mana pejabat bankpemilik otoritas telah menjalankan kewenangannya dengan benar.Beberapakasus pembobolan bank dalam kegiatan jasalayanan umumnya terjadi akibatkelalaian dalam dua hal tersebut.

\section{Pembobolan Bank}

1. Pembobolan bank mengalami perubahan bentuk ke arah yang semakincanggih sesuai dengan perkembangan teknologi dan kompleksitas transaksikeuangan.Tingkat keamanan bank menjadi dipertaruhkan ketika frekwensi danskala pembobolan menjadi semakin besar.Penipuan, penggelapan, dan korupsikorporasi (corporate corruption) merupakan ancaman yang serius terhadapsistem keuangan.

Sebagai lembaga intermediasi keuangan, pembobolan bank dapat terjadi disetiap tahapan proses bisnis dalam sebuah bank. Sesuai dengan fungsinya,pembobolan dapat terjadi dalam:

1. Pembobolan terhadap dana simpanan dimana dana nasabah digerogotioleh oknum bankir tanpa sepengetahuan nasabah

2. Pembobolan kredit dimana oknum bankir secara sengaja merekayasakerugian bank melalui transaksi kredit fiktif atau kualitas kreditnya rendah

3. Pembobolan atas transaksi keuangan yang difasilitasi bank seperti kartukredit, transfer fiktif, transaksi valas yang merugikan dan lain-lain.

Pelaku pembobolan bank bisa merupakan pihak di dalam bank maupunpihak luar. Tetapi biasanya pihak luar sangat jarang melakukan pembobolantanpa ada kerjasama dengan pihak dalam bank (Saunders, 2002). Pembobolanyang murni dilakukan oleh pihak luar biasanya terbatas pada pembobolan kartukredit serta transaksi elektronis.Dengan semakin ketatnya prosedur pengamanantransaksi elektronis, praktis peluang pembobolan dari luar semakin tipis.Pembobolan yang dilakukan oleh pihak dalam bank semakin canggih dansemakin besar sesuai dengan tingkat jabatan pelaku.Otorisasi transaksi yangdapat dilakukan oleh pejabat bank disesuaikan dengan tingkatan jabatan.Semakin tinggi jabatan semakin besar otoritas transaksi yang menjadikewenangannya.Karena itu, pembobolan dalam sekala kecil biasanya dilakukanoleh pegawai di tingkat rendahan.Kasus pembebolan skala besar hanya mungkinterjadi di bank besar dan oleh pejabat bank dengan posisi tinggi. 


\section{Ragam Modus Kejahatan Perbankan}

1. Kegiatan yang dilaksanakan oleh Bank dalam rangka menghimpun dana ke masyarakat yang susah untuk dijamah oleh hokum, menurut Prof. Mardjono adalah :

- "window dressing": yaitu usaha bank agar menjelang periode laporan (misalnya kepada Bank Indonesia) meningkatkan jumlah "asset"/aktiva, agar penampilan bank menjadi lebih dan bonafide dimata masyarakat;

- Menetapkan tingkat bunga yang berlebihan; yang bertujuan menarik dana masyarakat sebanyak mungkin, dengan cara apapun dan dengan biaya berapapun (kegiatan ini dapat merupakan indikasi kurang sehatnya" operasi bank dan bermaksud melakukan proses “gali lobang tutup lobang”);

- Memberikan kemudahan dalam pemberian kredit dengan tidak disertai pertimbangan atau penilaian yang wajar dalam dunia bisnis perbankan; khususnya apabila kredit itu disalurkan kepada perusahaan-perusahaan di "lingkungan kelompoknya" dan dalam jumlah yang berlebihan;

- "menyalurkan informasi" tentang keadaan keuangan seorang nasabah bank, kepada pihak-pihak tertentu yang "dekat" dengan bank bersangkutan (pada hakekatnya melanggar ketentuan Pasal 39 UU Pokok Perbankan, tetapi tidak mudah untuk dibuktikan $)^{2}$

\section{C.1. Model Sendiri}

Pada kasus yang terjadi di Manado misalnya.Awalnya, seorang pegawaibank membuka rekening. Tentu bisa atas nama siapa saja. Setelah itu, aturstrategi mengisi rekening baru itu dari dana nasabah yang tersimpan di bank.

Untuk mengeruk dana, dilakukan dengan dua cara. Pertama, membuattransaksi fiktif, seolah-olah nasabah yang diincar telah transaksi bisnis, sehinggaperlu melakukan pembayaran ke sebuah rekening [yang sudah dibuat pegawaibank tadi.Tanda tangan nasabah dipalsukan. Maka, sejumlah dana langsungberpindah, karena pegawai bank tersebut terlibat langsung dalam sistem validasi.

Kedua, dengan cara lebih sederhana. Pencairan dana dilakukan tidak lewatmodus transaksi fiktif, tapi cukup dengan memalsukan tanda tangan

\footnotetext{
${ }^{2}$ Mardjono Reksodiputro, 2007, Bunga Rampai Permasalahan Dalam Sistem Peradilan Pidana; Buku Ke Lima, Pusat Pelayanan Keadilan Dan Pengabdian Hukum, Jakarta.
} 
nasabahyang bersangkutan untuk menarik dana. Kemudian, disetor ke rekening yangsudah disiapkan.

Kerja secara individu membobol dana nasabah bisa juga dilakukan secaraoffline. Polanya sama, yaitu memalsukan tandatangan nasabah dalam slippenarikan, kemudian mencairkan di bank cabang yang berbeda. Biasanya, yangmencairkan tidak dia sendiri, melainkan minta bantuan pihak lain.

Modus lain, bisa dilakukan oleh seorang pegawai bank yang tugasnya hanyamembuat kartu anjungan tunai mandiri (ATM). Orang dengan tugas seperti inibisa mengaktifkan kembali ATM yang sudah mati, kemudian diberikan nomorPIN milik nasabah lain yang masih aktif.Ketika dana digelontorkan, seakan-akan yang menarik adalah nasabahpemilik rekening sendiri. Padahal, pegawai bank dengan kartu ATM asli yangdiberi nomor PIN palsu.

\section{C.2. Model Berkelompok}

Modus dengan kelompok agak lebih rumit, karena membutuhkan otoritas lebih dari satu pihak.Bisa satu, jika yang melakukan pemegang otoritas tertinggi,seperti Kepala Cabang. Sebab, biasanya terkait dengan dana besar.

Seperti yang terjadi di BRI Senen.Seorang Kepala Cabang memalsukantanda tangan seorang nasabah yang memiliki tabungan berbentuk depositoberjangka.Ia sadar, nasabah tersebut tergolong "kakap" dengan melihat jumlahdananya yang tersimpan.

Setelah menemukan mangsa itu, Kepala Cabang membuatkan sebuah suratpalsu tentang permohonan kredit atas nama nasabah tadi. Jaminannya, depositoyang ada di bank tersebut [cash collateral].Kredit pun cair dengan tanda tanganpersetujuan dari Kepala Cabang yag bersangkutan.Karena pencairan kredit, dipinjam pula sebuah perusahaan milik rekannyadi luar.Dan, dananya langsung masuk ke rekening perusahaan pinjaman itu.Pemilik perusahaan "abal-abal" itu, langsung mencairkan dananya danmemindahkan ke rekening lain agar tak terlacak. Biasanya dalam bentuk yangberbeda, misalnya rekenng giro.Pencairannya bisa di mana saja.Model yang mirip dengan di atas ada juga, yakni melalui surat perintahpalsu. Otoritas bank di cabang memalsukan surat perintah transfer dana nasabahke sebuah rekening, yang tentu merupakan milik anggota komplotannya. 
Jadi,pemalsu surat dan pemilik otoritas merupakan orang yang sama. Kalaupunberbeda, mereka dipastikan saling berhubungan atau berkonspirasi.

Masih banyak lagi modus kejahatan korupsi dibidang perbankan, akan tetapi yang penulis uraikan disini hanya contoh kasus diatas

\section{E. Kesimpulan}

1. Kejahatan perbankan pada umumnya dapat digolongkan sebagai corporate corruption atau yaitu korupsi yang terjadi dalam sebuahperusahaan. Tetapi dalam bahasa hukum formal, bisa sajadikategorikan kedalam tindak pidana kejahatan biasa (pemalsuan,penipuan dll) maupun tindak pidana korupsi.

2. Dari sisi penerima kerugian, kejahatan perbankan dapat digolongkan menjadi empat: (1) kejahatan yang merugikan negara atau penjaminsimpanan, (2) kejahatan yang murni merugikan nasabah, (3) kejahatanyang murni merugikan bank, dan (4) kejahatan yang merugikannasabah dan bank.

3. Dari sisi pelaku, kejahatan perbankan dapat digolongkan menjadi tigajenis yakni: (1) kejahatan yang dilakukan oleh pihak dalam bank, (2) kejahatan yang dilakukan oleh pihak di dalam bank dan (3) kejahatanyang dilakukan pihak dalm dan luar bank secara bersama-sama. Padaumumnya tingkat kerugian yang diciptakan hanya oleh pelaku di luarbank relatif kecil saja. Kerugian yang lebih besar justru tercipta jikaorang dalam bank terlibat.

\section{F. Daftar Pustaka}

Mardjono Reksodiputro, Kemajuan Pembangunan Ekonomi dan Kejahatan; Buku Ke Satu, Pusat Pelayanan Keadilan Dan Pengabdian Hukum, Jakarta, 2007.

Mardjono Reksodiputro, Bunga Rampai Permasalahan Dalam Sistem Peradilan Pidana; Buku Ke Lima, Pusat Pelayanan Keadilan Dan Pengabdian Hukum, Jakarta, 2007.

M. Zen Abdullah, Kapita Selecta Hukum Pidana, Hasta Cipta Mandri, Yogyakarta, 2009. 